\title{
Convention on the Rights of the Child: Educational Opportunities and Social Justice
}

\author{
Foreword \\ Zdenko Kodelja, Educational Research Institute, Slovenia \\ Urška Štremfel, Educational Research Institute, Slovenia
}

1

his double issue of Šolsko polje has two parts. The first part is a thematic issue on the Convention on the Rights of the Child, particuThe second part is the Varia issue, containing discussions on various actual educational research topics.

The United Nations Convention on the Rights of the Child was adopted in 1989 . The main novelty it brought is its recognition of liberty rights for children, that is, a special kind of rights to freedom of speech, religion, assembly etc., sometimes called "participatory rights" as well. However, although these freedoms are ascribed to all children, only some children can actually exercise them. For, liberty rights are rights of choice, which presupposes the autonomy of the subject of those rights. Therefore, only someone who is capable of making rational judgements, choices and decisions can exercise them. But the problem is that the Convention does not specify when children are able to freely take reasonable decisions regarding exercising or not the liberty rights the Convention recognises for them. In addition, the right of children to freedom of religion, which is one of the liberty rights, is in conflict with the parents' right to educate their children in accordance with their own, that is, parents', religious convictions. This right of the child is closely related to the right to education. There is no doubt that this right, whose exercise appears to be taken for granted in the developed world, is violated for many people and in many places. We can see this easily from the information that more than Ioo million children are deprived of the most basic education. These and similar figures show two things. On one hand, they bear witness to the 
injustice suffered by millions of children in different parts of the world; on the other, they highlight the vast differences in the global distribution of educational opportunities. Because educational opportunities are essential to ensuring equal opportunities and since without equality of opportunity there is no social justice, it is clear that great injustices are being done in the world in which we live. Yet, the injustices resulting from violations of the right to basic education as a fundamental human and child right are far from equally distributed. They mainly occur in the most underdeveloped and extremely poor countries. This means the nationality or membership of a particular nation is today a much stronger factor affecting the inequality of opportunity than are race, gender or even talent and ability, as it is nationality that determines different educational opportunities and labour market access and to quite unequal systems of social rights. However, this stands in stark contrast with the traditional concept of social justice, which requires that those who have the same abilities and an equal will to learn must not simply have equal opportunities for education but also for success in education, irrespective of their social status, race, nationality, religion etc. Still, is it necessary and appropriate to expand this understanding of justice to the global level?

The five articles in this thematic issue address these and other challenges of realising the Convention on the Rights of the Child from different perspectives, theoretical and empirical backgrounds. The first three articles discuss these issues on a global level.

Zoe Moody in her article Children's Rights to, in and through Education: Challenges and Opportunities addresses the practical implications and challenges of providing schools as an ideal space/save haven in which children's rights are fully respected and implemented. By employing a descriptive approach through the prism of the concepts of diversity, participation and social transformation, she exposes how unrealistic or even idealistic this goal currently is. She explains why ensuring access to quality education and effectively removing exclusionary practices are still global concerns with regard to ensuring that all children are entitled, as subjects of the law, to acquire knowledge and skills, notwithstanding characteristics like gender, citizenship, migrant status, disability status, socio-economic status, sexual orientation, ethnic background, family language, religion and imprisonment. She indicates a few solutions to help move towards the effective transformative education that would support the full realisation of children's rights in and through education.

In the article Implementation and Protection of the Child's Right to Education, Suzana Kraljić reviews instruments provided by important international human and child's rights treaties that have improved access 
to education from a legal perspective. She asks in particular which protection is given in selected cases of infringements of a child's right to education and how has the European Court of Human Rights decided with respect to attempts to limit the child's right to education. Given the evidence she provides and the current COVID-19 situation, she concludes that as an international community and states we still have a long way to go to ensure full implementation and protection of the child's right to education.

Jelena Vranješević in her article Convention on the Rights of the Child and Adultism: How to Deconstruct a Myth? sheds light on an important dilemma in the assurance of child rights - the question of the image of the child. Considering the 3-Ps formula (protection, provision and participation), she focuses on participation as a concept of evolving capacities that allow children to be actively involved in all decisions that might affect them, thus opposing the dominant "regimes of truth" in respect of the child's image as an immature, incomplete and passive object of adults' care and protection. She discusses the controversies of adultism as an oppressive practice towards children and reveals the potential held by the Convention on the Rights of the Child to deconstruct this myth.

Two more articles discuss realising the Convention on the Rights of the Child in a certain national - Slovenian - context.

The article of Marjan Šimenc and Zdenko Kodelja in their article The Realisation of the Right to Education in Slovenia examines realisation of the right to education under Articles 28 and 29 of the Convention on the Rights of the Child. It particularly focuses on selected areas of the education of Roma children, the quality of knowledge and private education, topical areas relevant for enforcing the Convention not only in Slovenia, but also on the global level.

Urban Boljka, Jasmina Rosič and Tamara Narat in their article Who Calls the Shots? The Insiders and Outsiders of (Un)just Participation in Slovenian Elementary Schools deals with inequalities in exercise of the right to participate in elementary schools in Slovenia. The empirical research findings reveal that, according to the Rawlsian approach to the conceptualisation of justice and Fraser's recognition approach, child participation in Slovenian schools is lacking in substantive equality in participation outcomes.

Instead of a conclusion to the thematic issue, Zdenko Kodelja discusses other problems with children's rights, namely, the relationship between human and children's rights; the controversy over children's liberty rights; and the antinomy of rights. 
Discussions in this thematic issue confirm that children's rights are an ambiguous and controversial issue. They point to several, but surely not all of the, challenges in realising the Convention on the Rights of the Child. By contributing to existing academic discussions, they are certain to also lead to new research agendas in the field.

The Varia issue consists of two articles in English and two in the Slovenian language. Mornar et al. in their article Students' Social, Emotional and Intercultural Competencies and their Development in School Settings provides a thorough review of the content, theoretical and conceptual background, methodological and organisational aspects of existing interventions for developing SEI competencies. Their evaluation shows the general effectiveness of such interventions. Due to the multiple similarities of the two revealed thus far in what are mainly separate approaches (social and emotional learning on one side and intercultural learning on the other), the authors provide arguments for their integration into further school-based interventions in the field.

The article Public Universities in Post-Socialist States Could Become 'Un-Academic' after the 2020 Pandemic may be understood as a critical essay in which Andraž Teršek expresses standpoints, poses critical views, devises hypotheses, raises doubts and opens controversial issues about the contemporary state of public universities in Slovenia from the standpoint of their values, academic autonomy, recent changes in their complex positions and structures, approaches to teaching and their role in social and cultural contexts. His critical views are supported by selected scientific evidence, an interview with a like-minded scholar, and public debates on these controversial issues.

Janez Drobnič in his article Vocational Decisions and Career Guidance in the Context of Autonomy and Self-determination provides an extensive review of the changes in career management that have occurred in recent years due to a dynamic economy and labour market, as well as the influences of modern approaches deriving from career development theories. He presents a synthesised competence career model for persons with special needs based on modern career management approaches.

Andreja Drobnič Vidic's article Comparison of Two Interdisciplinary Student-centred Learning Approaches for Incorporation in the Field of Mathematics deals with terminological and didactical questions of applying inquiry-based learning (IBL) and problem-based learning (PBL) in Slovenian mathematics education. Based on a thorough qualitative analysis, it shows the shortcomings of the recent inclusion of these approaches 
in the field of mathematics and provides guidelines for successful interdisciplinary mathematics teaching.

In addition, two reviews are included in this issue. Pacale Emily Pečnik review the book Children's Rights, Educational Research and the UNCRC: Past, Present and Future edited by Fillett-Swan and Coppock. The second review is by Maja Dolinar and presents Hyslop-Margison and Thayer's book Teaching Democracy: Citizenship Education as Critical Pedagogy.

This issue ends with a report from the roundtable "Research between politics and science over the last four decades", organised as a tribute to the formal end of the research path of Prof. Dr. Darko Štrajn, the long-time editor of Šolsko polje. 